\title{
Erratum to: Measuring the spatial impacts of urbanization on the surface water resource basins in Istanbul via remote sensing
}

\section{Mehmet Kucukmehmetoglu • Abdurrahman Geymen}

Published online: 20 November 2009

(C) Springer Science + Business Media B.V. 2009

\section{Erratum to: Environ Monit Assess (2008) \\ 142:153-169 \\ DOI 10.1007/s10661-007-9917-6}

The original version of this article unfortunately contained mistakes.

The first sentence in the Method section on page 156 should have read: "The overall flow diagram of the methodology used is shown in Fig. 3 (based on Cetin et al. 2008)".

The caption for Figure 3 on page 158 should have read: "Fig. 3. Flow diagram of the methodology used (based on Cetin et al. 2008)".

The online version of the original article can be found at http://dx.doi.org/10.1007/s10661-007-9917-6.

M. Kucukmehmetoglu Department of City and Regional Planning, Gebze Institute of Technology,

Kocaeli, Turkey

A. Geymen $(\varangle)$

Engineering Faculty, Geodesy and Photogrammetry

Engineering Department, Erciyes University,

38039 Kayseri, Turkey

e-mail: ageymen@erciyes.edu.tr
The following reference should have been included:

Çetin, M., Musaoglu, N., \& Tanik, A. (2008). Multitemporal assessment of land-use change in a rapidly urbanizing coastal region in Turkey using remote sensing. Environmental Engineering Science, 25, 917-928. 